\title{
ULCERUL VARICOS CRONIC GIGANT. OBSERVAȚII CLINICE ASUPRA DOUĂ CAZURI
}

\author{
Virag Tiberiu' \\ ${ }^{1}$ CMI, medic specialist medicina familiei
}

\section{Title: The giant varicose ulcer. Clinical observations regarding of two cases}

Abstract: I present two cases of giant varicose ulcer who exceed over $20 \mathrm{~cm}$ in diameter, of which one healed and the other is in treatment, at two female patients aged 70 years. The varicose ulcers supervene in both cases at patients with former cronic vein circulatory deficiency, due to reccurent trombophlebitis caused by long term bed immobilisation with severe coxartrosis.

Key words: varix, legg edema, hiperpygmentation, stasis dermatitis, varicose ulcer, eczema.

Rezumat: Prezint două cazuri de ulcer varicos gigant cu diametru de peste $20 \mathrm{~cm}$, unul vindecat, iar celălalt în tratament, la două persoane de sex feminin de peste 70 de ani. Ulcerele varicoase apar în ambele cazuri la paciente cu antecedente de insuficiență venoasă cronică, datorită episoadelor de tromboflebită ca urmare a imobilizării la pat, ambele paciente având și o coxatroză bilaterala avansată.

Cuvinte cheie: varice, edemul membrelor inferioare, hiperpigmentația, dermatita de stază, ulcerul varicos, eczematizare periulceroasă.

\section{Introducere}

Ulcerul varicos cronic se manifestă prin pierderea de substantă cutanată, care evoluează fară tendință de vindecare spontană și se dezvoltă pe fondul unei insuficiențe venoase cronice [1].

Ulcerul din boala varicoasă are sediul de preferință în regiunea maleolară internă, în special la gamba stângă (77\%), restul localizării fiind de 4\% în 1/3 inferioară a gambei, 16\% în 1/3 medie, 3\% la nevelul piciorului [2].

Vârsta de apariție a ulcerului varicos este sub 30 de ani în 8\% din cazuri, între 30 și 60 de ani $30 \%$, peste 60 de ani în $62 \%$ [1].

Cauzele ulcerelor varicoase ale membrelor inferioare sunt multiple [3]:

-factori favorizanți: ortostatismul prelungit, imobilizare la pat îndelungată, boli cardio-vasculare

-afecțiuni vasculare: venoase, arteriale, vasculite, limfatice

-neuropatii

-afecțiuni metabolice

-afecțiuni hematologice

-traumatisme

-infecții

-paniculite

Ulcerele varicoase apar datorită disfuncției congenitale sau dobândite a valvulelor venelor profunde și/sau comunicante, ce duce la stază venoasă [3]. Manifestarea care precede sau însoțește ulcerele varicoase este edemul, care determină anoxie locală și în timp duce la dermatită pigmentară și purpurică. Anoxia tisulară duce la eliberarea de histamină și serotonină, rezultatul fiind inflamația de tip eczematos a tegumentelor. Stagnarea sângelui în vene, leziunile peretelui vascular venos și suprainfecția, duc la apariția tromboflebitei varicoase și a ulcerului varicos [4]. Suprainfecția ulcerului 
varicos se face cel mai frecvent cu stafilococ aureu hemolitic (65-70\%), streptococ $\beta$ hemolitic (10$14 \%)$, proteus, colibacili, piocianic, etc. [5].

Ulcerele cronice cu tendințe la vindecare au baza curată, granulată, cu marginile regulate. Când nu au tendință de vindecare marginile sunt neregulate (Foto 1), acoperite cu puroi și țesuturi sfacelate. În ulcerele vechi caloase, marginile leziunii sunt îngroșate, infiltrate proeminent și cu duritate lemnoasă. Aceste ulcerații sunt însoțite de durerii vii și hiperestezie, rebele la tratament. Pielea din jurul ulcerului este sediul unei dermatite eczematiforme uscate sau umede.

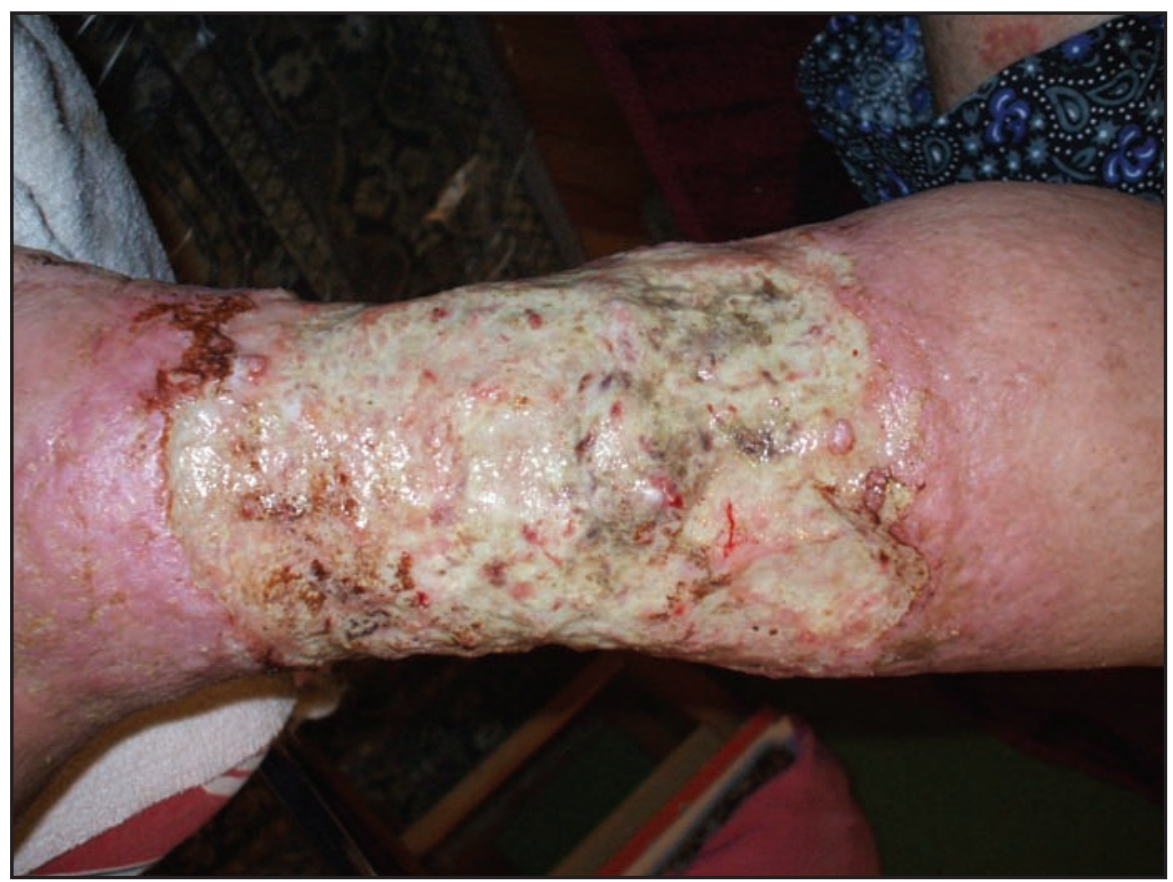

Fig. 1

Diagnosticul ulcerului varicos se pune pe seama examenului clinic și paraclinic.

Clinic: evidențierea insuficienței venoase cronice, cauza frecventă a ulcerului de gambă, proba celor trei garouri. Examenul clinic local ne dă informații despre mărimea ulcerului, marginile, dermatita, edemul, hiperpigmentația ulcerului cu baza curată, sau suprainfectată cu cruste galbene de fibrină, acesta necesitând tratament chirugical.

Examenul paraclinic: flebografie, doppler, radiografii, examen histopatologic, examinări de laborator, culturi bacteriene, fotopletismografia [3].

Diagnosticul diferențial include: vasculita, piodermita gangrenoasă, ulcerații arteriale, traumatisme, înțepături de insecte, siclemia.

\section{Prezentarea cazurilor}

Am luat în studiu două cazuri de ulcer varicos cronic gigant, suprainfectate bacterian și eczematizate.

Caractere clinice comune:

-localizare în 1/3 inferioară a gambei, zonele maleolare interne si externe, cu diametre de peste $20 \mathrm{~cm}$. -survin pe un teren de flebotromboză.

-au fost suprainfectate cu stafilococ aureu hemolitic.

-sunt cronice, nevindecate de peste 4 ani.

-este prezent limfedemul, cu picior elefantiazic și eczematizarea periulceroasă.

-vârsta de peste 70 ani, sex feminin, cu coxartroză bilaterală și insuficiență cardiacă. 
Cazul nr. 1: sex feminin, 76 de ani, având în antecedente varice ale membrului inferior drept, cu insuficiență cardiocirculatorie compensată și o insuficiență venoasă cronică moștenită familial. Insuficiența venoasă, în timp, datorită ortostatismului prelungit și insuficienței cardiace ca factor adjuvant, a determinat apariția edemului de stază, cu flebotromboza profundă a membrului inferior drept și apariția ulcerului varicos, cu o evoluție pe parcusul a cinci ani, ajungând la dimensiunea de 20 cm; în ianuarie 2009 se complică cu hemoragie venoasă. Se internează de urgență pe secția chirurgie unde este operată, la 7 zile se externează deoarece refuză efectuarea grefei de piele, moment din care am preluat cazul și am aplicat un tratament sistemic și local.

Sistemic: clindamicynum 3x300 mg/zi 7 zile, pentoxiphyillinum 3x400 mg/zi.

Local: stimularea granulației cu soluție nitrat de argint 1\%, îngrijirea tegumentelor periulceroase cu pastă zincată, eczema a fost tratată cu ungvent cu betametazonă și gentamicină.

Ulcerul varicos s-a vindecat la 2 luni de la operație (Foto 2).

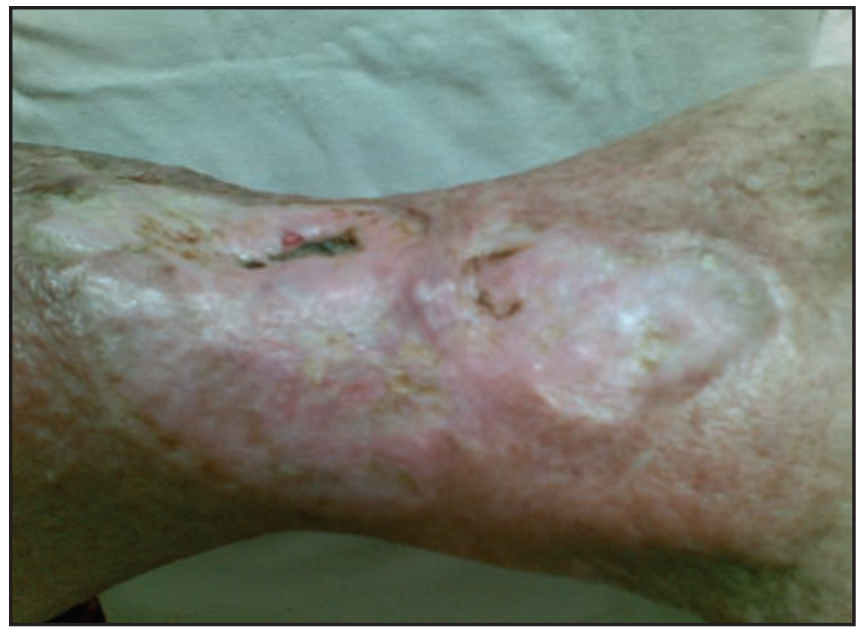

Fig. 2

Profilactic în acest caz se recomandă tratamentul ICC, utilizarea de ciorapi compresivi pentru reducerea edemului, control lunar pentru prevenirea complicațiilor erizipeloide și a edemelor membrelor inferioare.

Cazul nr. 2: sex feminin, 70 ani, prezintă de aproximativ patru ani un ulcer varicos la nivelul membrului inferior drept în $1 / 3$ inferioară a gambei, cu dimensiunea de peste $20 \mathrm{~cm}$, ulcerație ce înconjoară gamba. Ulcerul varicos evoluând cronic de peste patru ani, a devenit calos, cu marginile dure, pe suprafață prezentând depozite purulente determinate de stafilococul aureu hemolitic (Foto 3).

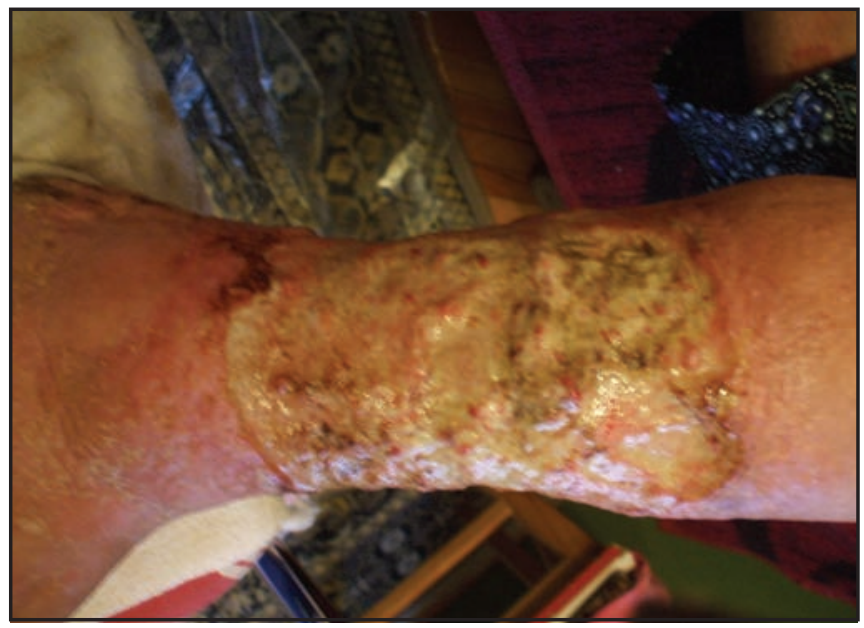

Fig. 3 
Tegumentul din jurul ulcerului este pigmentat, inflamat, eczematizat.

Deoarece pacienta are o coxartroză bilaterală invalidantă, refuză internarea în secția de chirurgie, fiind de acord cu inițierea tratamentului la domiciliu.

Terapia sistemică: conform antibiogramei cu ceftriaxonum $2 \mathrm{~g} / \mathrm{zi}$ intravenos în perfuzie cu glucoză $5 \%$ opt zile, apoi tratament per oral cu ciprofloxacinum $2 \times 500 \mathrm{mg} / \mathrm{zi}$, pentoxiphillinum 3x400mg/zi, metronidazolum $3 \times 1$ tablete/zi.

Terapia generală: corectarea stazei venoase prin repaus la pat, tratament cu flebotonice diosmimum 2x1 tb/zi, debridarea ulcerului pentru curațirea țesuturilor necrotice, a sfacelurilor și a puroiului cu acid boric 3\%, excizia sfacelurilor după anestezie locală prealabilă.

Tratament cicatrizant local cu soluție de nitrat de argint 3\%, mercurcrom $0,5 \%$ și general cu xintrom $2 \mathrm{mg} / \mathrm{zi}$, ultraviolete 15 minute.

Tratament vasodilatator cu tolazolin, nifedipinum $10 \mathrm{mg} \mathrm{2x1/zi.}$

Tratament antiinflamator cu nimesulidum $100 \mathrm{mg} 1$ plic/zi.

Tratament tranchilizant cu doxepinum $1 \mathrm{tb} / \mathrm{zi}$.

Tratamentul eczemei periulceroase cu ungvent cu betametazonă și gentamicină.

Reducerea edemelor prin repaus la pat, tratamentul insuficientei cardio-circulatorii și a hipertensiunii arteriale cu diuretice și cardiotonice.

Evoluția cazului 2 este prezentată succesiv în fotografiile 4-8.

Rezolvarea favorabilă a cazurilor a fost posibilă datorită îndeplinirii a patru criterii:

1. tratarea complicațiilor care au aparut pe parcurs: hemoragie venoasă, limforagia, reacția alergică, inflamația și șocul dureros

2. asigurarea finanțării tratamentului

3. repaus absolut la pat

4. prezența unei terțe persoane ce a asigurat igiena corporală generală precum si toaleta locală a plăgii

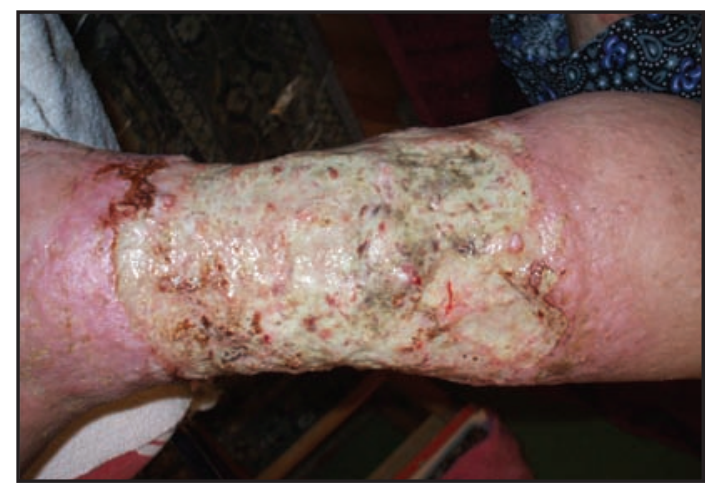

Fig. 4. 30.05.2009 Ulcer infectat

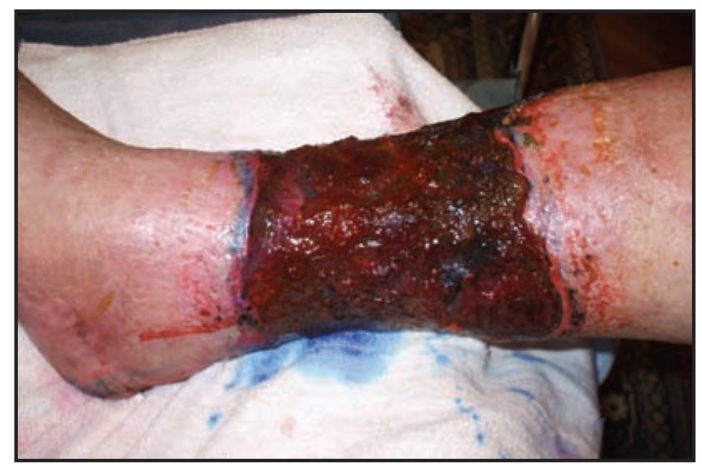

Fig. 6. 18.06.2009 Țesut de granulație pregătit pentru acoperire cu peliculă de protecție

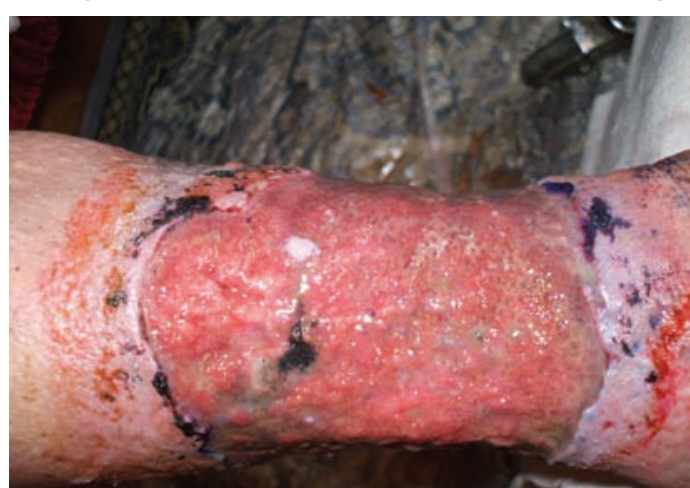

Fig. 5. 16.06.2009 Țesut de granulație

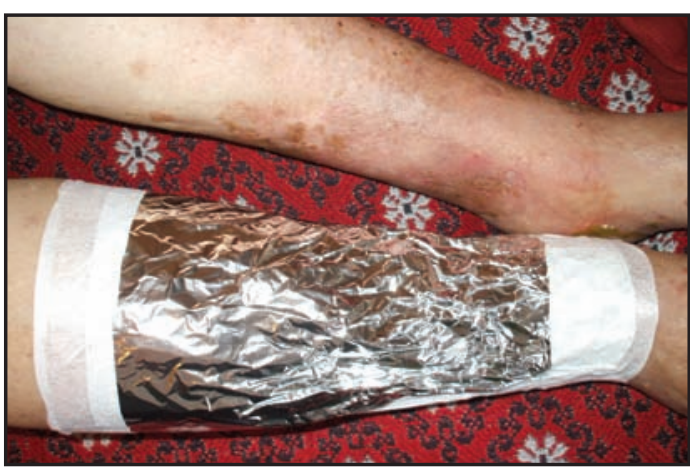

Fig. 7. 18.06.2009 Folierea în vederea formării peliculei 


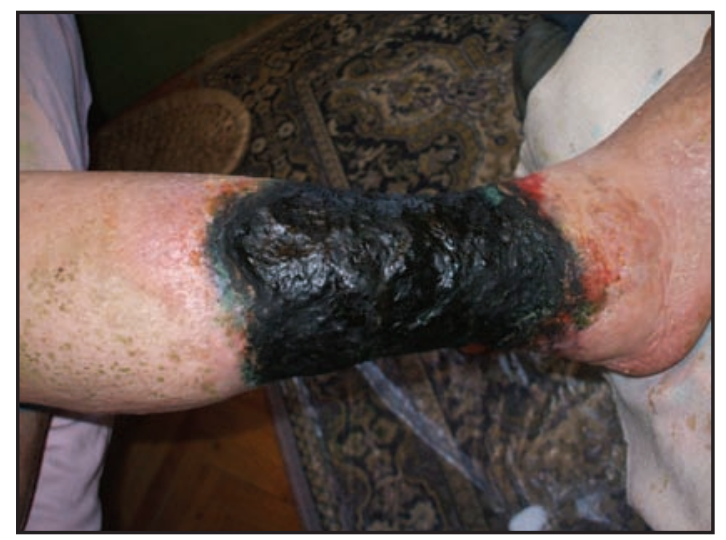

Fig. 8. 24.06.2009 Ulcer vindecat în proporție de $80 \%$, cu peliculă de protecție, urmează definitivarea epitelizării în decurs de 2-3 luni

\section{Concluzii}

Ulcerele varicoase au o evoluție cronică care necesită luni și ani de zile de îngrijiri medicale, cu tendință la recidivă și complicații și costuri ridicate.

Pot fi de forme clinice variate, de la dimensiuni mici pâna la forme gigante, cu margini neregulate, unele superficiale, altele profunde, suprainfectate și eczematizate.

Se recomandă tratamentul corect al insuficienței venoase cronice, atât profilactic compresiv, medicamentos, cât și chirurgical dacă este cazul, pentru a nu se ajunge la formele de ulcere varicoase gigant.

\section{Referințe}

1. Coltoiu, A, Mateescu, S, Popescu, S. Dermato-venerologie, București, Ed. Didactică și pedagogică, 503-507.

2. Maier, N. Patologie cutanată, vol II, Cluj Napoca, Casa Cărții de Știință, 267-276.

3. Forsea, D, Popescu, R, Popescu, CM. Compendiu de dermatologie și venerologie, București, Ed. Tehnică, 258-263.

4. Tierney, LM, Mc.Phee, SF, Papadachis, MA. Diagnostic și tratament în practica internațională, Ediție internațională Mc. Graw Hill, 144.

5. Conu, A. Dermato-venerologie, București, Ed. Didactică și Pedagogică, 366. 